American Journal of Animal and Veterinary Sciences 5 (4): 266-273, 2010

ISSN 1557-4555

(C) 2010 Science Publications

\title{
The Effect of Heat or Heat-Xylose Processing on Nitrogen Fractions and in Situ/In Vitro Ruminal and Post-Ruminal Protein Disappearance of Guar Meal
}

\author{
Hossein Jahani-Azizabadi, Mohsen Danesh Mesgaran, \\ Ali Reza Vakili, Moosa Vatandoost, Einollah Abdi Ghezeljeh and Mohsen Mojtahedi \\ Department of Animal Science (Excellence Centre for Animal Science), \\ Faculty of Agriculture, Ferdowsi University of Mashhad, Mashhad, Iran
}

\begin{abstract}
Problem statement: Guar meal is a by-product consisting of hull and germ and is mostly used as a protein source in poultry and ruminant rations. The aim was to determine the effect of heat or heat-xylose processing on nitrogen fractions, in situ ruminal degradation parameters and in situ/in vitro ruminal and post-ruminal disappearance of guar meal. Approach: Samples were intact Guar Meal $(\mathrm{GM})$, heat processed $\mathrm{GM}\left(\mathrm{GM}_{\mathrm{hp}}\right.$, $\mathrm{GM}$ was heated at $100^{\circ} \mathrm{C}$ for 45 minute using industrial heater) and heat-xylose processed $\mathrm{GM}\left(\mathrm{GM}_{\mathrm{hx}}\right.$, xylose was included in GM to give a final concentration of $10 \mathrm{~g}$ $\mathrm{kg}^{-1} \mathrm{DM}$, then was heat processed at $100^{\circ} \mathrm{C}$ for 45 minute using industrial heater). Ruminal degradation parameters of DM and Crude Protein (CP) were determined by in situ technique using four ruminally fistulated sheep. Post-ruminal disappearance of ruminal-undegradable $\mathrm{CP}$ was determined on residue from $16 \mathrm{~h}$ ruminal incubation of guar meal samples by three-step in situ/in vitro enzymatic procedure. Results: Non-protein nitrogen of the $\mathrm{GM}_{\mathrm{hx}}$ and GM samples ranged from 218-319 $\left(\mathrm{g} \mathrm{kg}^{-1}\right.$ $\mathrm{N})$. Acid detergents insoluble nitrogen concentration of both GM and GMhp was significantly lower than that of $\mathrm{GM}_{\mathrm{hx}}\left(10.3,11.29\right.$ and $18.53 \mathrm{~g} \mathrm{~kg}^{-1}$ nitrogen, respectively). In situ fractional degradation rate constant (c) of DM and $\mathrm{CP}$ was significantly decreased as a result of heat-xylose processing. Effective crude protein degradability of $\mathrm{GM}_{\mathrm{hp}}$ and $\mathrm{GM}_{\mathrm{hx}}$ was higher than that of GM. Post-ruminal disappearance of ruminal-undegradable $\mathrm{CP}$ of $\mathrm{GM}_{\mathrm{hx}}(0.965)$ was significantly higher compared with $\mathrm{GM}$ and $\mathrm{GM}_{\mathrm{hp}}$ (0.918 and 0.906, respectively). Conclusion: Results of the present study demonstrated that heat and heat-xylose processing might effectively protect the DM and $\mathrm{CP}$ of guar meal from ruminal degradation.
\end{abstract}

Key words: guar meal, degradability, nitrogen fractions, Trichloroacetic Acid (TCA), heat-xylose processed, NPN concentration, reducing sugars, pharmaceuticals manufacturing, germ plus, dry heat, monogastric animals, Crude Protein (CP), Dry Matter (DM), Ether Extract (EE)

\section{INTRODUCTION}

Guar (Cyamopsis Tetragonoloba) is a sub-tropic resistant legume that mostly is cultivated in India peninsula. The main purpose for growing this plant is production of guar bean's gum. Guar bean consist of hull (14-17\% of bean), endosperm (35-42\% of bean) and germ ( $43-47 \%$ of bean). This seed has a large endosperm which contains a significant amount of mannogalactan called gum. It has many industrial applications, such as paper making, cosmetics and pharmaceuticals manufacturing, explosives and producing textiles and carpets (Rahman and Leighton, 1968). Isolation of mannogalactan from guar bean yields a high protein by-product which consists of germ (high protein product) or germ plus hull and residual of gum (low protein product). This is mostly used as a source of protein in ruminant and monogastric animals (Conner, 2002). To remove some of the beans odour and gum residual from Guar Meal (GM), it is toasted being subjected to steam and dry heat (Rahman and Leighton, 1968). Feeding characteristics and other properties of GM have been well evaluated in poultry nutrition (Couch et al., 1967; Verma and McNab, 1982; Lee et al., 2003a; 2003b; 2005; Hassan et al., 2008). However, few experiments have been done to evaluate the chemical composition and nutritive value of different guar meals for ruminant nutrition. Different methods have been applied to decrease the rumen degradability of protein of various oilseed meals, including treatment with heat (Mir et al., 1984; Nakamura et al., 1994a, Vanhatalo et al., 1995),

Corresponding Author: M. Danesh Mesgaran, Department of Animal Science (Excellence Centre for Animal Science),

Faculty of Agriculture, Ferdowsi University of Mashhad, Mashhad, Iran 
formaldehyde (Mir et al., 1984), lignosulfonate (McAllister et al., 1993) and reducing sugars such as xylose (Wallace and Falconer, 1992; McAllister et al., 1993; Harstad and Prestlokken, 2000; Can and Yilmaz, 2002; Tunce and Sacaki, 2003). Heat processing has the advantage of increasing protein resistant to rumen degradability and enhance the amount of protein entering small intestinal. However, heating above the optimal temperature might result in the over-protection of protein to ruminal degradation and intestinal digestion (Dakowski et al., 1996). Heat-xylose treatment might decrease ruminal protein degradation that occurs via Maillard reaction between aldehydes group of xylose and amino acid (Van Soest, 1989). The aim of the present study was to evaluate the effect of heat or heat-xylose processing on chemical composition, nitrogen fractionations, in situ ruminal Dry Matter (DM) and Crude Protein (CP) degradation and ruminal and postruminal CP disappearance using three-step in situ/in vitro enzymatic procedure (3-step) of guar meal.

\section{MATERIALS AND METHODS}

Commercial production of guar gum is normally undertaken by using the process of roasting, differential attrition, sieving and polishing. Selected guar split is screened to clean and then soaked to pre-hydrate in a double cone mixer. Soaked splits, which have reasonably high moisture content, are passed through a flaker. The flaked guar split is ground to the desired particle size, followed by drying of the material. The powder is then screened through rotary screens to deliver required particle size. Using heating, grinding and polishing process, the husk is separated from the endosperm halves and the refined guar gum split is obtained. This isolation from the beans yields a byproduct named intact Guar Meal (GM). In many industrial, it has been exposed to the further heat processing to extract the guar residual.

Experimental samples were intact GM, heat processed GM (GMhp, GM was processed at $100^{\circ} \mathrm{C}$ for $45 \mathrm{~min}$ using industrial heater) and heat-xylose processed GM (GMhx, xylose was included in GM to give a final concentration of $10 \mathrm{~g} \mathrm{~kg}^{-1} \mathrm{DM}$ and heat processed as $100^{\circ} \mathrm{C}$ for 45 minute using industrial heater).

Samples were ground to pass through a $2 \mathrm{~mm}$ screen and then analyzed for Organic Matter (OM), Nitrogen (N), Ether Extract (EE) and ash (AOAC, 1990). Neutral Detergent Fibre (NDF) not assayed with a heat stable amylase and expressed exclusive of residual ash and acid detergent fibre exclusive of residual ash (ADF) were determined using the method of Van Soest et al. (1991). Nitrogen fractions [NonProtein Nitrogen (NPN), buffer insoluble nitrogen,
Neutral Detergent Insoluble Nitrogen (NDIN) and Acid Detergent Insoluble Nitrogen (ADIN) were determined as proposed by Licitra et al. (1996).

In situ rumen degradability of $\mathrm{DM}$ and $\mathrm{CP}$ of the samples were determined using polyester bag procedure. Approximately, $5 \mathrm{~g}$ DM of each sample was placed in a bag $(9 \times 17 \mathrm{~cm}$; pore size of $52 \mu \mathrm{m}, 10$ bags per each sample) and incubated in the rumen for 2, 4, 8, 12, 16, 24 and $48 \mathrm{~h}$. For $0.0 \mathrm{~h}$, bags were washed with cold tap water ( 5 minute with gently hand pressure) until water was clear. Four sheep $(49.5 \pm 2.5 \mathrm{~kg})$ fitted by rumen fistulae were used. The animals were fed with $1.5 \mathrm{~kg}$ DM of Lucerne hay and $0.4 \mathrm{~kg}$ DM concentrates (165 $\mathrm{g} \mathrm{CP} \mathrm{kg}^{-1}$ of DM) per head per day. After removal the bags from the rumen, were washed under tap water and subsequently dried using an oven dryer $\left(60^{\circ} \mathrm{C}, 48\right.$ h), then weighed to determine DM disappearance. Then, $\mathrm{N}$ concentration of rumen un-incubated and incubated samples was determined using Kjeldahl method (Kjeltec 2300 Auto analyzer, Foss Tecator AB, Hoganas, Sweden.

This stage of the experiment followed the 3-step procedure proposed by Danesh Mesgaran and Stern (2005). Ruminal disappearance of CP from the samples was determined using in situ bag procedure. Approximately, $5 \mathrm{~g}$ DM of each sample (15 bags per each feed) was placed in polyester bag $(9 \times 17 \mathrm{~cm}$, with pore size of $52 \mu \mathrm{m}$ ) and incubated in the rumen of the sheep for $16 \mathrm{~h}$. Bags were placed simultaneously in the rumen before the morning feeding and after removal from the rumen, they were washed under tap water until water was clear and subsequently dried using an oven dryer $\left(60^{\circ} \mathrm{C}, 48 \mathrm{~h}\right)$. Samples from the incubated ruminal residues were taken for $\mathrm{N}$ analysis using Kjeldahl method (Kjeltec 2300 Auto analyzer, Foss Tecator AB, Hoganas, Sweden). Then, a part of ruminal undegradable CP from the in situ bags was weighed into a $50 \mathrm{~mL}$ polypropylene centrifuge tube (each sample contained $15 \mathrm{mg}$ of $\mathrm{N}, 4$ tubes per each sample). Two blank tubes were also prepared to correct the $\mathrm{N}$ contribution of the enzymes. Ten $\mathrm{ml}$ of pre-warmed $\left(37^{\circ} \mathrm{C}\right) \mathrm{HCl}-$ pepsin solution $[2 \mathrm{~g}$ of pepsin (Merck M785) dissolved into $1 \mathrm{~L}$ of $0.1 \mathrm{~N} \mathrm{HCl}$ ] was placed in each tube. Tubes were vortexes and incubated for $1 \mathrm{~h}$ in a shaking incubator at $38.6^{\circ} \mathrm{C}$ (Parsazma, Iran). After 1 h of incubation, $0.5 \mathrm{~mL}$ of $1 \mathrm{~N} \mathrm{NaOH}$ solution was added to each tube and then vortexes. The procedure continued by adding $13.5 \mathrm{~mL}$ of phosphate-pancreatin buffer $\left(68 \mathrm{~g}\right.$ of $\mathrm{KH}_{2} \mathrm{PO}_{4}$ per $1 \mathrm{~L}$ of distilled water, $37^{\circ} \mathrm{C}$ ). The $\mathrm{pH}$ was adjusted to 7.8 with strong $\mathrm{NaOH}$, followed by the addition of $6 \mathrm{~g}$ of pancreatin (Merck, M-7130). Tubes were vortexes and incubated for $24 \mathrm{~h}$ in a shaking incubator at $38.6^{\circ} \mathrm{C}$. After incubation, 3 $\mathrm{mL}$ of Trichloroacetic Acid (TCA) solution (100 g of TCA $100 \mathrm{~mL}^{-1}$ of distilled water) was added to each 
American J. Animal \& Vet. Sci., 5 (4): 266-273, 2010

tube, then vortexes. The tubes were left for $15 \mathrm{~min}$ and then centrifuged at $10,000 \mathrm{~g}$ for $15 \mathrm{~min}$. A part of the supernatant $(5 \mathrm{~mL})$ was pipetted from each tube to determine the $\mathrm{N}$ concentration using the Kjeldahl method (Kjeltec 2300 Autoanalyzer, Foss Tecator AB, Hoganas, Sweden).

Calculation and statistical analysis: In situ disappearance of the DM and CP was calculated as the difference between the un-incubated and those remained after the incubation.

In situ disappearance data were fitted using an exponential equation (Fathi Nasri et al., 2006) of $\mathrm{P}=\mathrm{a}^{+}$ $\mathrm{b}\left(1-\mathrm{e}^{-\mathrm{ct}}\right)$; where $\mathrm{P}$ is potential of degradability, a is quickly degradable fraction, $\mathrm{b}$ is slowly degradable fraction; $\mathrm{c}$ is constant rate of degradation and $\mathrm{t}$ is incubation time (h). Effective Degradability (ED) of $\mathrm{DM}$ and $\mathrm{CP}$ was calculated using the parameters of $\mathrm{a}, \mathrm{b}$ and $\mathrm{c}$ at ruminal outflow rate $(\mathrm{kp})$ of 0.05 and $0.08 \mathrm{~h}^{-1}$, according to the equation described by Orskov and McDonald (1979); $\mathrm{ED}=\mathrm{a}+\mathrm{b} \cdot \mathrm{kp} /(\mathrm{c}+\mathrm{kp})$. Data of in situ/ in vitro enzymatic procedure were used to calculate the ruminal and post-ruminal CP disappearance as described by Calsamiglia and Stern (1995). Data were subjected to statistical analysis using the GLM procedure of SAS with the flowing statistical model (SAS Institute, 1999); $\mathrm{Yij}=\mu+\mathrm{Ti}+\mathrm{Eij}$; where Yij $=$ depended variable, $\mu=$ overall mean, $\mathrm{Ti}=$ effect of processing and Eij $=$ residual error. Tukey test was used for the comparing of the means at $p<0.05$.

\section{RESULTS}

The chemical composition and nitrogen fractions of the guar meal samples used in the present experiment are shown in Table 1 and 2, respectively. Heat processed $\mathrm{GM}\left(\mathrm{GM}_{\mathrm{hp}}\right)$ and $\mathrm{GM}_{\mathrm{hx}}$ had higher $(\mathrm{p}<0.05)$ EE (75.2 and $71.9 \mathrm{~g} / \mathrm{kg} \mathrm{DM}$, respectively) and CP (580 and $594 \mathrm{~g} / \mathrm{kg}$ DM, respectively) than those of GM (36.1 and $556 \mathrm{~g} / \mathrm{kg} \mathrm{DM}$, respectively). Heat and heat-xylose processing caused an increase $(\mathrm{p}<0.01)$ in the NDFNDIP and ADF concentration of $\mathrm{GM}_{\mathrm{hp}}$ and $\mathrm{GM}_{\mathrm{hx}}$ compared with GM (Table 1).

Non-protein nitrogen value of $\mathrm{GM}_{\mathrm{hx}}$ was lower $(\mathrm{p}<0.01))$ than those of $\mathrm{GM}$ and $\mathrm{GM}_{\mathrm{hp}}(218,319$ and $297 \mathrm{~g} \mathrm{~kg}^{-1} \mathrm{~N}$, respectively). The $\mathrm{GM}_{\mathrm{hx}}$ and $\mathrm{GM}_{\mathrm{hp}}$ samples had greater proportion $(\mathrm{p}<0.01)$ of $\mathrm{N}$ in the buffer insoluble $\mathrm{N}$ fraction compared with $\mathrm{GM}$ (16.2 and $9.76 \%$, respectively). Neutral detergent insoluble nitrogen content of $\mathrm{GM}_{\mathrm{hp}}$ and $\mathrm{GM}_{\mathrm{hx}}$ was higher $(p<0.01)$ than that of GM (Table 2). Heat-xylose processing caused an increase $(\mathrm{p}<0.01)$ of the ADIN concentration of $\mathrm{GM}_{\mathrm{hx}}$ compared whit those of GM and $\mathrm{GM}_{\mathrm{hp}}\left(18.5,10.3\right.$ and $11.3 \mathrm{~g} \mathrm{~kg}^{-1} \mathrm{~N}$, respectively).
Table 1: Chemical composition of the guar meal $\left(\mathrm{g} \mathrm{kg}^{-1}\right.$ of DM)

\begin{tabular}{|c|c|c|c|c|c|}
\hline \multirow[b]{2}{*}{ Nutrients } & \multicolumn{5}{|c|}{ Feed samples* } \\
\hline & GM & $\mathrm{GM}_{\mathrm{hp}}$ & $\mathrm{GM}_{\mathrm{hx}}$ & SEM & P-value \\
\hline Organic matter & 948.0 & 948.5 & 948.5 & 0.27 & 0.04 \\
\hline Crude protein & $566.0^{\mathrm{a}}$ & $580.0^{\mathrm{b}}$ & $594.0^{\mathrm{c}}$ & 4.10 & 0.04 \\
\hline Ether extract & $36.1^{\mathrm{a}}$ & $75.2^{\mathrm{b}}$ & $71.9^{\mathrm{b}}$ & 1.30 & $<0.01$ \\
\hline NDFom- NDIP ${ }^{\mathrm{t}}$ & $218.0^{\mathrm{a}}$ & $238.0^{\mathrm{b}}$ & $238.0^{\mathrm{b}}$ & 6.07 & $<0.01$ \\
\hline ADFom ${ }^{\text {t }}$ & $131.0^{\mathrm{a}}$ & $140.0^{\mathrm{b}}$ & $140.0^{\mathrm{b}}$ & 2.00 & $<0.01$ \\
\hline Ash & $52.0^{\mathrm{a}}$ & $50.9^{\mathrm{b}}$ & $51.7^{\mathrm{ab}}$ & 0.27 & 0.04 \\
\hline
\end{tabular}

$\mathrm{GM}=$ intact guar meal; $\mathrm{GM}_{\mathrm{hp}}=$ overheat processed $\mathrm{GM}$; $\mathrm{GM}_{\mathrm{hx}}=$ overheat-xylose processed GM' NDFom- NDIP = neutral detergent fiber not assayed with a heat stable amylase and expressed exclusive of residual ash which corrected for neutral detergent insoluble crude protein. ${ }^{\mathrm{A}} \mathrm{ADF}$ om $=$ acid detergent fibre expressed exclusive of residual ash. ${ }^{a, b, c}$ Means with difference letter in each row were significant

Table 2 Nitrogen fractionations of the guar meal samples Feed sample*

\begin{tabular}{lccccc} 
Nitrogen fractions & $\mathrm{GM}$ & $\mathrm{GM}_{\mathrm{hp}}$ & $\mathrm{GM}_{\mathrm{hx}}$ & $\mathrm{SEM}^{\mathrm{\ddagger}}$ & $\mathrm{P}-$ value \\
\hline $\begin{array}{l}\text { Non-protein nitrogen } \\
\left(\mathrm{g} \mathrm{kg}^{-1} \mathrm{~N}\right)\end{array}$ & $319.0^{\mathrm{a}}$ & $297.0^{\mathrm{a}}$ & $218.0^{\mathrm{b}}$ & 8.76 & $<0.01$ \\
$\begin{array}{l}\text { Buffer insoluble } \\
\text { nitrogen }\left(\mathrm{g} \mathrm{kg}^{-1} \mathrm{~N}\right)\end{array}$ & $666.0^{\mathrm{a}}$ & $731.0^{\mathrm{b}}$ & $774.0^{\mathrm{c}}$ & 9.10 & $<0.01$ \\
$\begin{array}{l}\text { Neutral detergent insoluble } \\
\text { nitrogen }\left(\mathrm{g} \mathrm{kg}^{-1} \mathrm{~N}\right)\end{array}$ & $55.0^{\mathrm{a}}$ & $104.0^{\mathrm{b}}$ & $118.0^{\mathrm{c}}$ & 3.20 & $<0.01$ \\
$\begin{array}{l}\text { Acid detergent insoluble } \\
\text { nitrogen }\left(\mathrm{g} \mathrm{kg}^{-1} \mathrm{~N}\right)\end{array}$ & $10.3^{\mathrm{a}}$ & $11.3^{\mathrm{a}}$ & $18.5^{\mathrm{b}}$ & 1.20 & $<0.01$ \\
\hline
\end{tabular}

${ }^{*} \mathrm{GM}=$ intact guar meal; $\mathrm{GM}_{\mathrm{hp}}=$ overheat processed $\mathrm{GM} ; \mathrm{GM}_{\mathrm{hx}}=$ overheat-xylose processed GM ${ }^{\mathfrak{t}} \mathrm{SEM}=$ standard error of means ${ }^{\mathrm{a}, \mathrm{b}, \mathrm{c}}$ Means with difference letter in each row were significant

Table 3: In situ ruminal Dry Matter (DM) and Crude Protein (CP) degradation parameters of the guar meal samples (mean \pm SEM)

\begin{tabular}{llll}
\hline & \multicolumn{2}{l}{ Feed sample $^{*}$} & \\
& $-\mathrm{GM}$ & $\mathrm{GM}_{\mathrm{hp}}$ & $\mathrm{GM}_{\mathrm{hx}}$ \\
\hline Parameters & & & \\
\hline DM degradability parameters & $0.20 \pm 0.03$ & $0.23 \pm 0.03$ & $0.21 \pm 0.02$ \\
$\mathrm{a}$ & $0.80 \pm 0.03$ & $0.77 \pm 0.04$ & $0.79 \pm 0.03$ \\
$\mathrm{~b}$ & $0.12 \pm 0.01^{\mathrm{a}}$ & $0.09 \pm 0.01^{\mathrm{b}}$ & $0.07 \pm 0.01^{\mathrm{c}}$ \\
$\mathrm{c}\left(\mathrm{h}^{-1}\right)$ & 0.89 & 0.94 & 0.95 \\
$\mathrm{R}^{2}$ & 0.73 & 0.69 & 0.64 \\
Effective degradability $\left(\mathrm{kp}=0.05 \mathrm{~h}^{-1}\right)$ & 0.60 & 0.54 \\
Effective degradability $\left(\mathrm{kp}=0.08 \mathrm{~h}^{-1}\right)$ & 0.64 & 0.60 & \\
$\mathrm{CP}$ degradability parameters & & & \\
$\mathrm{a}$ & $0.10 \pm 0.01$ & $0.09 \pm 0.04$ & $0.07 \pm 0.04$ \\
$\mathrm{~b}$ & $0.90 \pm 0.05$ & $0.91 \pm 0.06$ & $0.93 \pm 0.06$ \\
$\mathrm{c}(/ \mathrm{h})$ & $0.11 \pm 0.01^{\mathrm{a}}$ & $0.08 \pm 0.01^{\mathrm{b}}$ & $0.06 \pm 0.01^{\mathrm{c}}$ \\
$\mathrm{R}^{2}$ & 0.87 & 0.93 & 0.92 \\
Effective degradability $\left(\mathrm{kp}=0.05 \mathrm{~h}^{-1}\right)$ & 0.71 & 0.65 & 0.57 \\
Effective degradability $\left(\mathrm{kp}=0.08 \mathrm{~h}^{-1}\right)$ & 0.60 & 0.54 & 0.46 \\
\hline
\end{tabular}

$\mathrm{GM}=$ intact guar meal; $\mathrm{GM}_{\mathrm{hp}}=$ overheat processed $\mathrm{GM} ; \mathrm{GM}_{\mathrm{hx}}=$ overheat-xylose processed $\mathrm{GM}^{* *}: \mathrm{a}=$ quickly degradable fraction; $\mathrm{b}=$ non-soluble degradable fraction; $\mathrm{c}=$ constant rat of degradation $\left(\mathrm{h}^{-1}\right)$.

$\mathrm{a}, \mathrm{b}, \mathrm{c}$ : Means with difference letter in each row were significant $(p<0.05) .{ }^{\mathrm{F}} \mathrm{kp}=$ ruminal out flow rat. SEM $=$ Standard Error of Means

In situ DM and CP degradation parameters of the samples are presented in Table 3. The fractional degradation rate $(\mathrm{c})$ of DM was decreased $(\mathrm{p}<0.05)$ as a result of both heat and heat-xylose processing $(\mathrm{GM}=$ 0.12, $\mathrm{GM}_{\mathrm{hp}}=0.09$ and $\left.\mathrm{GM}_{\mathrm{hx}}=0.07\right)$. In addition, applying of heat and heat-xylose processing on the samples decreased the effective degradability of DM. 
Table 4:Ruminal (after $16 \mathrm{~h}$ incubation) and post-ruminal disappearance of ruminal un-degraded crude protein of the guar meal samples

\begin{tabular}{|c|c|c|c|c|c|}
\hline \multirow[b]{2}{*}{ Items } & \multicolumn{5}{|c|}{ Feed sample } \\
\hline & $\mathrm{GM}^{*}$ & $\mathrm{GM}_{\mathrm{hp}}$ & $\mathrm{GM}_{\mathrm{hx}}$ & SEM $^{\ddagger}$ & P-value \\
\hline Ruminal disappearance & $0.960^{\mathrm{a}}$ & $0.840^{\mathrm{b}}$ & $0.700^{\mathrm{c}}$ & 0.03 & $<0.01$ \\
\hline $\begin{array}{l}\text { Post-ruminal } 0.918^{\mathrm{a}} \\
\text { disappearance } \\
\text { of ruminal-undegraded }\end{array}$ & $0.906^{\mathrm{a}}$ & $0.965^{\mathrm{b}}$ & 0.008 & $<0.01$ & \\
\hline Total tract disappearance & $0.997^{\mathrm{a}}$ & $0.985^{\mathrm{b}}$ & $0.990^{\mathrm{b}}$ & 0.001 & $<0.05$ \\
\hline
\end{tabular}

Heat and heat-xylose processing did not have any effects $(p>0.05)$ on both $a$ and $b$ fractions of CP (Table 3), while the rate of $\mathrm{CP}$ degradation of $\mathrm{GM}_{\mathrm{hx}}$ was lower $(p<0.05)$ than those of the other samples (Table 3). Effective CP degradability (calculated for $\mathrm{kp}$ $=0.05 \mathrm{~h}^{-1}$ ) of $\mathrm{GM}_{\mathrm{hp}}$ and $\mathrm{GM}_{\mathrm{hx}}$ were 8.5 and $20 \%$ less than of GM. This effect was more obvious when $\mathrm{kp}$ was assumed at $0.08 \mathrm{~h}^{-1}$ (90 and $76 \%$ of GM, for $\mathrm{GM}_{\mathrm{hp}}$ and $\mathrm{GM}_{\mathrm{hx}}$, respectively).

Data of ruminal (16 h incubation), post-ruminal and total tract $\mathrm{CP}$ disappearances are presented in Table 4. Results of the present study indicate that heat and heat-xylose procedures cause a decrease $(\mathrm{p}<0.01)$ in ruminal $\mathrm{CP}$ disappearance of $\mathrm{GM}(\mathrm{GM}=0.96$, $\mathrm{GM}_{\mathrm{hp}}=0.84, \mathrm{GM}_{\mathrm{hx}}=0.70$ ). Post-ruminal disappearance of ruminal undegradable $\mathrm{CP}$ of $\mathrm{GM}_{\mathrm{hx}}$ was higher $(p<0.01)$ than those of the other samples (Table 4). It was also indicated that heat and heat-xylose processing decreases $(\mathrm{p}<0.01)$ in total tract $\mathrm{CP}$ disappearance of $\mathrm{GM}_{\mathrm{hp}}$ and $\mathrm{GM}_{\mathrm{hx}}\left(\mathrm{GM}=0.997, \mathrm{GM}_{\mathrm{hp}}=0.985, \mathrm{GM}_{\mathrm{hx}}=0.990\right)$.

\section{DISCUSSION}

Heat and heat-xylose processing applied in the present study caused a significant increase in CP, EE and NDF content of final products (Table 1). Approximately, $35-42 \%$ of guar bean is mannogalactan gum while the germ concentration is $43-45 \%$ (Conner, 2002). In contrast to the other compartments of guar bean, germ has a high $\mathrm{CP}$ and $\mathrm{EE}$ concentration $(0.55$ and 0.052 per $\mathrm{kg} \mathrm{DM}$, respectively). In gum production industry, mannogalactan residual is extracted from guar meal by subjecting it to steam and dry heating over than initial heat process which applied to extract gum (Rahman and Leighton, 1968). Therefore, steam and dry heat processing of guar meal tended to increase the proportion of germ and hull in the residual which caused to increase proportion of CP, EE and NDF in the guar meal.

The solubility of any feed protein source in acidic or basic solution is a practical procedure which is proposed by Cornell Net Carbohydrate and Protein system (Sniffen et al., 1992; Licitra et al., 1996) to evaluate the value of ruminant feedstuffs. Results of the present study indicate that heat-xylose processing is an effective procedure to decrease NPN concentration of GM as previously observed by Fathi Nasri et al. (2008) used whole soybeans. The reduction in NPN concentration due to heat and heat-xylose processing was likely due to the loss of amino acid. Ljokjel et al. (2000) and Dakowski et al. (1996) reported that heat processing caused to loss of labile essential and non-essential amino acids. The NPN concentration in $\mathrm{GM}_{\mathrm{hx}}$ was almost 32.5 and $26.5 \%$ lower $(\mathrm{p}<0.01)$ than those of $\mathrm{GM}$ and $\mathrm{GM}_{\mathrm{hp}}$, respectively. Results of the present experiment indicate that NPN concentration of the guar meals ranged from $21-32 \%$. These values are higher than the values reported for soybean meal (2.4-22.5, percent of total $\mathrm{N})$ as a reference protein source (NRC, 2001).

Less in the buffer soluble $\mathrm{N}$ fraction of $\mathrm{GM}_{\mathrm{hx}}$ and $\mathrm{GM}_{\mathrm{hp}}$ in contrast with GM $(-47.8$ and $-24.2 \%$, respectively) suggested that buffer soluble $\mathrm{N}$ fraction was probably more responsive to heating and heatxylose processing. An increase in the neutral detergent insoluble nitrogen fraction as a result of heat and heatxylose processing was probably due to the denaturation and Maillard reaction of the proteins as this has been shown to reduce their solubility (Van Soest, 1994).

Heat processing applied in the present study caused to 1.8 times increase in ADIN concentration of guar meal, but. It has been proposed that xylose is a reducing sugar which causes to occur Maillard reaction and increase in ADIN concentration when combined with a feed protein source (Nakamura et al., 1994b). It has been assumed that ADIN might use as an indicator to estimate the ruminal and post-ruminal unavailable nitrogen (Goering et al., 1972; Yu and Thomas, 1976; Pichard and Van Soest, 1977; Sniffen et al., 1992). However, various workers indicated that ADIN was a poor indicator of nitrogen digestibility in forage and concentrate feedstuffs (Nakamura and Britton, 1994b; Jahani-Azizabadi et al., 2007).

As it was expected, the changes produced by heat and heat-xylose processing in the chemical composition of the samples evaluated caused an alter in the ruminal degradation parameters of the samples. Quickly degradable fraction (a) of the guar meal samples was slightly affected $(\mathrm{p}>0.05)$ with heat and heat-xylose processing.

Decrease in the fractional degradation rate (c) and effective DM and CP degradability of heat and heatxylose processed guar meal samples might be a response of formation of low-digestible lignin-like polymers (Van Soest and Mason, 1991). Furthermore, 
the formation of soluble phenolic compounds which have a depressing effect on ruminal DM degradation might be the other alternative (Lopez et al., 1995). Present results indicate that heat and heat-xylose processing caused to decrease the amount of material available to rumen microbes and this confirmed the findings of Pereira et al. (1998). In addition, results obtained by the present experiment confirmed the previous results suggesting that reducing sugars had a potential to alter ruminal degradability of protein sources such as soybean and canola meals (McAlister et al., 1993; Stanford et al., 1995; Tuncer and Sacakli, 2003; Rooke, 1985).

The lower effective CP degradability of both $\mathrm{GM}_{\mathrm{hp}}$ and $\mathrm{GM}_{\mathrm{hx}}$ demonstrated that the chemical and physical changes produced by heat and heat-xylose processing increased the proportion of intermediate and slowly degradable fractions of nitrogen (Table 2) which confirmed the results of previous workers (Broderick and Craig, 1980; Pereira et al., 1998; Tunce and Sacakli, 2003). Heat and heat-xylose processing, which stimulate Maillard reaction between aldehydes group of reducing sugars and free amino group (Martins et al., 2001), might increase resistance of the $\mathrm{GM}_{\mathrm{hx}}$ protein to ruminal degradation. In the study of Tunce and Sacakli (2003), in which the effect of different levels of xylose $(0.5,1$ and $2 \%$ of DM) on degradation of soybean and canola meals was studied, ruminal CP degradability (24 $\mathrm{h}$ incubation) was lower than the untreated sample (at the rate of $37-67 \%$ for soybean meal and $1-21 \%$ for canola meal). However, the effect of heat-reducing sugar such as xylose on the extent of ruminal protein degradation depends on feed type and the concentration of reducing sugar (Hashiba, 1982), moisture content, both treatment temperature and time applied (Cleale et al., 1987; Broderick et al., 1993), amount of lysine content and epsilon amino group of lysine (Windschitl and Stern, 1988).

Results of the present experiment demonstrated that heat-xylose processing might decrease ruminal disappearance of $\mathrm{CP}$ with a positive effect on postruminal disappearance of ruminal undegradable protein. Chalupa (1974) suggested that Maillard reaction between sugar aldehydes group and free amino group might decrease ruminal degradation of protein without adversely affecting post-ruminal protein disappearance. Van Straalen et al. (1993) evaluated ruminal and postruminal $\mathrm{CP}$ disappearance of the grass and clover and reported that within forages lower ruminal degradability was recompensed by higher post-ruminal digestion (Jahani-Azizabadi et al., 2009). Ruminal, post ruminal and total tract CP disappearance of guar meal samples evaluated by the 3 -step in situ/in vitro enzymatic procedure showed that the value reported were higher than those of the other plant meals (Danesh Mesgaran and Stern, 2005; Danesh Mesgaran et al., 2008). Despite the significant difference in post-ruminal CP disappearance of $\mathrm{GM}_{\mathrm{hx}}$ with $\mathrm{GM}$, the amount of total tract indigestible $\mathrm{CP}$ of $\mathrm{GM}_{\mathrm{hx}}$ was very low $\left(10 \mathrm{~g} \mathrm{~kg}^{-1}\right.$ $\mathrm{CP}$ ). Therefore, the results of the present study indicated that CP of various guar meals evaluated was almost completely digestible in gastrointestinal tract of ruminants.

\section{CONCLUSION}

In conclusions, it has been indicated that the protein content in guar meal is well digestible in ruminant gastrointestinal tract. However, GM has higher ruminal degradability and NPN content compared with the heat and heat-xylose processed samples. Therefore, present results indicate that both heating and heating-xylose treatments are effective methods to alter the rumen degradation characteristics of DM and CP of GM. Results obtained by the present study indicate that the ruminal and post-ruminal disappearance of GM protein are influenced by the physical and physico-chemical methods applied. However, there is a need to evaluate more physical and chemical methods to alter the ruminal degradation of GM without any negative effect on the post-ruminal disappearance of ruminal un-degradable protein.

\section{ACKNOWLEDGEMENT}

The researchers wish to acknowledge the financial support received from the Ferdowsi University of Mashhad, Project Number 15184/2.

\section{REFERENCES}

AOAC, 1990. Association of Official Analytical Chemists. Official Methods of Analysis. 15th Edn., AOAC, Arlington, Virginia, USA.

Broderick, G.A. and W.M. Craig, 1980. Effect of heattreatment on ruminal degradation and escape and intestinal digestibility of cottonseed meal protein. J. Nutri., 110: 2381-2389. WWW. jn.nutrition.org/content/110/12/2381.full.pdf

Broderick, G.A., J.H. Yang and R.G. Koegel, 1993. Effect of steam heating alfalfa hay on utilization by lactating dairy cows. J. Dairy Sci., 76: 165-174. DOI: $10.3168 /$ jds.S0022-0302 (93)77335-X

Calsamiglia, S. and M.D. Stern, 1995. A three-step in vitro procedure for estimating intestinal digestion of protein in ruminants. J. Anim. Sci., 73: 14591465. WWW. jas.fass.org/cgi/reprint/73/5/1459 
Can, A. and A. Yilmaz, 2002. Usage of xylose or glucose as non-enzymatic browning agent for reducing ruminal protein degradation of soybean meal. Small Rumi. Rese., 46: 173-178. PII: S09214488(02)00197-9

Chalupa, W., 1974. Nitrogen metabolism in ruminant animals. In: Proceeding of the Guelph Nutritional Conference on Feed Manufacturers. J. Dairy Sci. 58: 1198-1218. www.journalofdairyscience.org

Cleale, I.V., R.M., Klopfenstein, T.J., Britton, R.A., Satterlee and S.R. Lowry, 1987. Induced nonenzymatic browning of soybean meal. I. Effects of factors controlling non-enzymatic browning on in vitro ammonia release. J. Anim. Sci., 65: 1312. www.jas.fass.org/cgi/reprint/65/5/1312

Conner, S., 2002. Characterization of guar meal for use in poultry rations. Ph.D. Dissertation. Texas A and M University, College Station, TX.

Couch, J.R., Y.K. Bakshi, T.M. Ferguson, E.B. Smith and C.R. Creger, 1967. The effect of processing on the nutritional value of guar meal for broiler chicks. Brit. Poultry Sci., 8: 243-250. DOI: 10.1080/00071666708415675

Dakowski, P., M.R. Weisbjerg and T. Hvelplund, 1996. The effect of temperature during processing of rape seed meal on amino acid degradation in the rumen and digestion in the intestine. Anim. Feed Sci. Technol., 58: 213-226. DOI: 10.1016/03778401(95)00868-3

Danesh Mesgaran, M. and M.D. Stern, 2005. Ruminal and post-ruminal protein disappearance of various feeds originating from Iranian plant varieties determined by the in situ mobile bag technique and alternative methods. Anim. Feed Sci. Technol., 118:31-46. 10.1016/J.ANIFEEDSCI.2004.10.009

Danesh Mesgaran, M., H. Jahani-Azizabadi and A.R. Heravi Moussavi, 2008. Comparison of techniques to determine the ruminal and post-ruminal protein disappearance of various oilseed meals. Rese. J. Biol. Sci., 3: 1028-1033. DOI: 10.3923/rjbsci.2008.1028.1033

Fathi Nasri, M.H., J. France, M. Danesh Mesgaran and E. Kebreab, 2008. Effect of heat processing on ruminal degradability and intestinal disappearance of nitrogen and amino acids in Iranian whole soybean. Livestock Sci., 113: 43-51. DOI: 10.1016/j.livsci.2007.02.017

Fathi Nasri, M.H., M. Danesh Mesgaran, J. France, J.P. Cant and E. Kebreab, 2006. Evaluation of Models to Describe Ruminal Degradation Kinetics from In Situ Ruminal Incubation of Whole Soybeans. J. Dairy Sci., 89: 3087-3095. DOI: 10.3168/jds.S0022-0302(06)72583-8
Goering, H.K., C.H. Gordon, R.W. Hemken, D.R. Waldo and P.J. Van Soest et al., 1972. Analytical estimates of nitrogen digestibility in heat damaged forages. J. Dairy Sci., 55: 1275-1280. PII: S00220302(72)85661-3

Harstad, O.M. and E. Prestlokken, 2000. Effective rumen degradability and intestinal indigestibility of individual amino acids in solvent-extracted Soybean Meal (SBM) and xylose-treated SBM (SoyPass) determined in situ. Anim. Feed Sci. Technol., 83: 31-47. DOI: 10.1016/S03778401(99)00114-5

Hashiba, H., 1982. The browning reaction of Amadori compounds derived from various sugars. Agric. Biol. Chem., 46: 547. www.journalarchive.jst.go.jp/jnlpdf

Hassan, S.M., A.K. El-Gayar, D.J. Cadwell, C.A. Bailey and A.L. Cartwright, 2008. Guar meal ameliorates Eimeria tenella infection in broiler chicks. Veter. Parasitol., 157: 133-138. DOI: 10.1016/j.vetpar.2008.07.005

Jahani-Azizabadi, H., M. Danesh Mesgaran, R. Valizadeh and H. Nasiri Moghadam, 2007. In situ ruminal disappearance of Acid Detergent Insoluble Nitrogen (ADIN) of various feeds. J. Anim. Sci., 85: Suppl. 1/J. Dairy Sci. Vol. 90, Suppl. 1/Poultry Science, Vol. 86, Suppl. 1, M297. WWW. adsa.asas.org/meetings/2007/abstracts/0096.PDF

Jahani-Azizabadi, H., M. Danesh Mesgaran, R. Valizadeh and H. Nasiri moghadam. 2009. Comparison of in vivo with in situ mobile bag and three step enzymatic procedures to evaluate protein disappearance of alfalfa hay and barley grain. Iranian J. Veteri. Res., 10: 260-266. www.shirazu.ac.ir/en/index.php?page_id=1823

Lee, J.T., C.A. Baile and A.L. Cartwright, 2003a. Guar meal germ and hull fractions differently affect growth performance and intestinal viscosity of broiler chickens. Poul. Sci., 82: 1589-1595. www.asn.co.com/PDF/Guar\%20meal\%20germ\%2 0and\%20hull\%20fraction.pdf

Lee, J.T., C.A. Bailey and A.L. Cartwright, 2003b. $\beta$ mannanase ameliorates viscosity-associated depression of growth in broiler chickens fed guar germ and hull fractions. Poul. Sci., 82: 1925-1931. WWW.ps.fass.org/cgi/reprint/82/12/1925.pdf

Lee, J.T., S. Connor-Appleton, C.A. Bailey and A.L. Cartwright, 2005. Effects of guar meal by-product with and without $\beta$-mannanase hemicell on broiler performance. Poul. Sci., 84: 1261-1267. WWW. ps.fass.org/cgi/reprint/84/8/1261.pdf 
Licitra, G., T.M. Hernandez and P.J. Van Soest, 1996. Standardization of procedures for nitrogen fractionation of ruminant feeds. Anim. Feed Sci. Technol., 57: 347-358. DOI: 10.1016/03778401(95)00837-3

Ljokjel, K, O. Magne Harstad and A. Skrede, 2000. Effect of heat treatment of soybean meal and fish meal on amino acid digestibility in mink and dairy cows. Anim. Feed Sci. Technol., 84: 83-95. DOI: 10.1016/S0377-8401(00)00104-8

Lopez, S., F.D.D.B. Hovell, B. Manyuchi and R.I. Smart, 1995. Comparison of sample preparation methods for determination of the rumen degradation characteristics of fresh and ensiled forages by the nylon bag technique. Anim. Sci., 60: 439-450. www.jas.fass.org

Martins, S.I.F.S., W.M.F. Jongen and M.A.J.S. Boekel, 2001. A review of Maillard reaction in food and implications to kinetic modelling. Food Sci. Technol., 11: 364-373. DOI: 10.1016/S09242244(01)00022-X

McAllister, T.A., K.J. Cheng, K.A. Beauchemin, D.R.C. Bailey and M.D. Pickard et al., 1993. Use of lignosulfonate to decrease the rumen degradability of canola meal protein. Canadian J. Anim. Sci., 73: 211-215. DOI: 10.4141/cjas93-022

Mir, Z., G.K. Macleod, J.G. Buchanan-Smith, D.G. Grýeve and W.L. Grovum, 1984. Methods for protecting soybean and canola proteins from degradation in the rumen. Canadian. J. Anim. Sci., 64: 853-865. DOI: $10.4141 /$ cjas84-099

Nakamura, T., T.J. Klopfenstein and R.A. Britton, 1994a. Evaluation of acid detergent insoluble nitrogen as an indicator of protein quality in nonforage proteins. J. Anim. Sci., 72: 1043-1048. WWW.jas.fass.org/cgi/reprint/72/4/1043.pdf

Nakamura, T., T.J. Klopfenstein, D.J. Gibb and R.A. Britton, 1994b. Growth efficiency and digestibility of heated protein feed to growing ruminants. J. Anim. Sci., 72: 774-782. WWW. jas.fass.org/cgi/reprint/72/3/774.pdf

National Research Council (NRC), 2001. Nutrient Requirement of Dairy Cattle. 7th Edn., National Academies Press, Washington D.C., ISBN: 10: 0309069971, pp: 450.

Orskov, E.R. and I. McDonald, 1979. The estimation of protein degradability in the rumen from incubation measurement weighted according to rate of passage. J. Agric. Sci. Cambridge, 92: 499-503. DOI: $10.1017 /$ S0021859600063048
Pereira, J.C., M.D. Carro, J. Gonzalez, M.R. Alvir and C.A. Rodriguez, 1998. Rumen degradability and intestinal digestibility of brewers' grains as affected by origin and heat treatment and of barley rootlets. Anim. Feed Sci. Technol., 74: 107-121. PII: S0377-8401(98)00168-0

Pichard, D.G. and P.J. Van Soest, 1977. Protein solubility of ruminant feeds. Proceeding of the Cornell Nutrition Conference, Ithaca, New York, pp: 91-98.

Rahman, M.S. and R.E. Leighton, 1968. Guar meal in dairy rations. J. Dairy Sci., 51: 1667-1671. DOI: 10.3168/jds.S0022-0302(68)87249-2

Rooke, J.A., 1985. The nutritive value of feed proteins and feed protein residues resistant to degradation by rumen microorganisms. J. Sci. Food Agric., 36: 629-637. DOI: 10.1002/jsfa.2740360802

SAS Institute, 1999. Statistical Analysis Systems user's guide. Version 8.2. SAS Institute, Inc., Cary, NC, USA.

Sniffen, C. J., J.D. O’Connor, P.J. Van Soest, D.G. Fox and J.B. Russell, 1992. A net carbohydrate and protein system for evaluating cattle diets: II. Carbohydrate and protein availability. J. Anim. Sci., $\quad 70: \quad 3562-3577$. www.jas.fass.org/cgi/reprint/70/11/3562

Stanford, K., T.A. McAllister, Z. Xu, M. Pickard and K.J. Cheng, 1995. Comparison of lignosulfonatetreated canola meal and soybean meal as rumen undegradable protein supplements for lambs. Canadian J. Anim. Sci., 75: 371-377. DOI: 10.4141/cjas95-056

Tuncer, S.D. and P. Sacakli, 2003. Rumen degradability characteristics of xylose treated canola and soybean meals. Anim. Feed Sci. Technol., 107: 211-218. Pii/S0377840103001172

Van Soest, P.J. and V.C. Mason, 1991. The influence of the Maillard reaction upon the nutritive value of fibrous feeds. Anim. Feed Sci. Technol., 32: 45-53. DOI: 10.1016/0377-8401(91)90008-G

Van Soest, P.J., 1989. On the digestibility of bound $\mathrm{N}$ in distiller's grains: A reanalysis. Proceeding of the Cornell Nutr. Conf. Feed Manuf. Cornell University, Ithaca, New York, pp: 127-135.

Van Soest, P.J., 1994. Nutritional Ecology of the Ruminant. 2nd Edn., Cornell University Press, Ithaca, New York, pp: 476.

Van Soest, P.J., J.B. Robertson and B.A. Lewis, 1991. Methods for Dietary Fibre, Neutral Detergent Fibre and Nonstarch Polysaccharides in Relation to Animal Nutrition. J. Dairy Sci., 74: 3583-3597. DOI: 10.3168/JDS.S0022-0302(91)78551-2 
Van Straalen, W.M., F.M.H. Dooper, A.M. Antoniewicz, Y. Kosmala and A.M. Van Vuuren, 1993. Intestinal digestibility in dairy cows of protein from grass and clover measured with mobile nylon bag and other methods. J. Dairy Sci., 76: 2970-2981. DOI: 10.3168/JDS.S00220302(93)77636-5

Vanhatalo, A., Y. Aronen and T. Varvikko, 1995. Intestinal nitrogen digestibility of heat-moisture treated rapeseed meals as assessed by the mobilebag method in cows. Anim. Feed Sci. Technol., 55: 139-152. DOI: 10.1016/0377-8401(95)00783-J

Verma, S.V.S. and J.M. McNab, 1982. Guar meal in diets for broiler chickens. Brit. Poul. Sci., 23: 95105. DOI: $10.1080 / 00071688208447935$
Wallace, R.J. and M.L. Falconer, 1992. In vitro studies of conditions required to protect protein from ruminal degradation by heating in the presence of sugars. Anim. Feed Sci. Technol., 37: 129-141. DOI: 10.1016/0377-8401(92)90125-P

Windschitl, P.M. and M.D. Stern, 1988. Evaluation of calcium lignosulfonate-treated soybean meal as a source of rumen protected protein for dairy cattle. J. Dairy Sci., 71: 3310-3322. DOI: 10.3168/JDS.S0022-0302(88)79936-1

$\mathrm{Yu}, \mathrm{Y}$. and J.W. Thomas, 1976. Estimation of the extent of heat damage in alfalfa haylage by laboratory measurements. J. Anim. Sci., 42: 766774. WWW.jas.fass.org/cgi/reprint/42/3/766 